\section{Prevalence of Parafunctional Habits in Dental Students from the Interior of the State of São Paulo, Brazil}

\section{Abstract}

There is a complex relationship between the stomatognathic system and the rest of the organism. One of the components of the temporomandibular joint, allows opening movements, closure, retrusion, and protrusion beyond the laterality of the mandible, being one of the complex joints of the human body and may suffer systemic or local changes. This study aims to verify the prevalence of some parafunctional habits in dentistry students at UNIFEB and demonstrate the need for early diagnosis, guidance and awareness to reduce possible damage to the stomatognathic system. This is an observational, transverse, descriptive and quantitative study to investigate a relation of some parafunctional habits in 106 students of the dentistry course aged between 18 and 33 years. We used questionnaires filled out by the researcher himself and, after this filling, the students were submitted to clinical examination to identify signs and sequels caused by parafunctional habits. The data collected were recorded in a clinical file and compared with the questionnaire data. The results obtained in the questionnaire, after analysis, showed that the variable that presented the highest percentage was of the students who support the chin with hands $64.15 \%(n=68)$. In relation to the other habits investigated, $52.86 \%(n=56)$ had teeth clenching, nail-gnawing $33.96 \%(n=36)$, teeth grinding and chewing on the cheek or tongue $29.25 \% n=31)$, the students who bite the lip $26,42 \%(n=28)$ and the one with the lowest index were those who bite some object $12,26 \%(n=13)$, besides that there was an association of habits in several students. In the clinical examination, it can be concluded that there was a high prevalence of parafunctional habits among these students, however, the most observed habit was bruxism, both in its centric and eccentric form. Due to the difference between the data of the questionnaire and those of the clinical examination, it was evident that the student does not have the perception of all the parafunctional habits that he presents, thus demonstrating the need for early diagnosis, orientation and awareness to reduce possible damages to the system stomatognathic.

Keywords: Bruxism; TJM; Signs and symptoms

Received: November 13, 2018; Accepted: November 27, 2018; Published: December 05, 2018

\section{Introduction}

There is a reciprocal and constant relationship between the various anatomical elements that constitute the stomatognathic system with the rest of the organism, both in the state of health (orthofunction) and in the disease (pato function) [1,2]. In general, parafunctional habits compromise compromised physiological components or comfort indexes and the ability to cause damage to bones, teeth and soft tissues [3-5].
Ana Carolina Bernardes

Vanzella ${ }^{1}$, Marcia Possato Almeida², Taylane Soffener Berlanga De Araújo 3*, Camila Leandra Polastrini Marques Ferreira ${ }^{3}$ Vera Lucia Bernardes 4 , Ceny Possato Almeida ${ }^{4}$ and Moacir Fernandes de Godoy ${ }^{5}$

1 Endodontics and Continuing Education (Unipos) SP, Brazil

2 Orthodonticsand Continuing Education (Unipos) SP, Brazil

3 University Center North Paulista (Unorp), Dental School - São José do Rio Preto-SP, Brazil and Post Graduate and Continuing Education (Unipos) SP, Brazil

4 Department of Dentistry and Temporary Mandibular Dysfunction, (Unipos) SP, Brazil

5 Department of Cardiology and Cardiac Surgery, School of Medicine of São José do Rio Preto-Famerp, Brazil

*Corresponding author:

Taylane Soffener Berlanga De Araújo

झ taylane@terra.com.br

Doctor in Restorative Dentistry, University Center North Paulista (Unorp) Dental School - São José do Rio Preto-SP, 15020-040, Brazil.

Tel: +55(17) 99761-3629/

+55(17) 98231-9889

Citation: Vanzella ACB, Almeida MP, Araújo TSBD, Ferreira CLPM, Bernardes VL, et al. (2018) Prevalence of Parafunctional Habits in Dental Students from the Interior of the State of São Paulo, Brazil. J Orthod Endod Vol.4 No.3:13 
These deleterious habits can occur when you are awake, awake, or asleep. Forms called diurnal or waking include dental tightening, centric (daytime/waking) and eccentric (night/unconscious) bruxism, lip biting, cheek or other objects, digital sucking, nailgnawing and inappropriate habits of posture, chewing gum, biting pencils, grinding or squeezing teeth that have diverse etiology, representing a way to release emotional tension [6-10].

The nocturnal or unconscious forms, also known as eccentric bruxism are multifactorial and the factors that contribute to this aetiology can be genetic, sleep structure, environment, stress, anxiety and psychological, elevation of catecholamines level, activation of the autonomic neural system with origin in the Central Nervous System (CNS) where the chewing muscles are activated [11], and the use of some drugs such as alcohol, tobacco, caffeine, etc. [6,10,12-14].

Central or waking bruxism is more often associated with occlusal instability, causing dental tightening with isometric muscular contraction, producing lactic acid production. Being more related to stress and parafunctional habits. In this type of bruxism, there is scalloped tongue and linea alba in the jugal mucosa [15].

These habits have been prominent within the dental context because they inhibit the normal blood flow of muscle tissues, causing accumulation of metabolic products in the cells of these tissues, triggering symptoms of fatigue, pain, spasm and apnea $[2,8,13]$.

Given the importance of early diagnosis of temporomandibular disorders, and knowing that parafunctional habits trigger changes in TMJ, anticipation of the diagnosis provides an adequate and timely treatment avoiding intervention at a more advanced stage of the dysfunction, where irreversible lesions may be established $[9,15]$.

Due to the complexity involved in the topic of parafunctional habits, from its aetiology, consequences for the stomatognathic system and therapeutic behaviors, the present work intends to evaluate the prevalence of some of these parafunctional habits in UNIFEB dental academics. And demonstrate the need for guidance and awareness of the risks of these habits, to reduce possible damage to the stomatognathic system.

\section{Literature Review}

The activities of the masticatory system are called functional and parafunctional, and the functional ones are chewing, swallowing and phonation, which enables the system to perform the necessary functions with minimal damage to the structures $[8,10]$. Any habit that escapes from functions considered normal to the stomatognathic system is considered parafunctional 10 . These are important in the aetiology of orofacial pain, and this painful sensation can vary greatly from patient to patient, as there is a threshold of tolerance with different individual biochemical and physiological responses to these factors $[9,16]$.

The parafunctional habits such as bruxism, dental tightening, nail-biting, among others, are related to the main etiological factors of TMD17, since they promote muscular hyperactivity $[17,18]$. These are important indications for the prevention and even supplementation of TMD treatment [19].
It has been argued that a parafunctional habit often triggers another habit, worsening the former, becoming a vicious cycle, or replacing it with another, calling this compensation mechanism [20].

Bruxism is one of the most common parafunctional habits found today and occurs unconsciously, and it can also occur in a more conscious way. This causes dental wear and periods of dental tightening $[2,21,22]$. It is one of the most destructive habits of the oral cavity occurring in a dysfunctional and constant way, using excessive forces for the dental and periodontal tissues [23].

The aetiology of bruxism, both centric and eccentric, is attributed to local, systemic, psychological and hereditary factors. Occlusal interferences can be considered as the main triggers of bruxism and this is a local factor [23-25]. Directly or indirectly, parafunctional habits influence the dental morphology, abnormal bone growth, respiratory and formation problems, poor dental positioning, altered oral motility and psychological disorders [26].

Several muscles and joint pathologies with the presence of pain and/or muscle fatigue are triggered by bruxism, tooth clenching among other parafunctional habits, and may even lead to limitation of joint movements in addition to cracking and crackling [27].

Regarding nail-biting, this can be considered as a form of selfmutilation and has been seen as a systematic behaviour, which reflects emotional distress or high anxiety. Some variations of this habit have been observed, such as biting the cuticles and the surrounding skin, lips and cheek, as well as chronic digital suction, which highlights multi- professional care for case resolution [28-30].

There is a high probability that parafunctional habits promote isometric muscle contraction which causes inhibition of blood flow to muscle tissues. Consequently, there is an increase of carbon dioxide in these tissues besides metabolic wastes which will cause fatigue, muscle spasms and pain, that is, collapse in the tissues, causing, over time, changes in the muscular system and the TMJ [31], which can cause symptoms such as headache, blurred vision, dizziness, ringing in the ear, and so on.

Mental parafunctional habits have long been believed to destabilize the stomatognathic system, and most patients exercise these habits in wakefulness, although they did not know the harm they caused [32,33].

Several studies have demonstrated the development of TMD in young individuals, culminating with the finding that university students develop and are potentially affected by parafunctional habits $[14,15,31,34]$. This is a phase of life in which young people undergo stress due to tensions and anxieties $[11,35]$ and the discharge of these nervous tensions on the musculature associated with muscular hyperactivity creates a greater propensity of TMD of muscular origin than to articulate in this specific group.

These findings coincide with the age range indicated in research [36], where the author stated that the highest incidence of parafunctional habits and mandibular cranial dysfunctions is from 21 to 30 years because it is a period of higher productivity of the society and greater psychological tension, stressing the most likely etiological factor for the development of such habits. 


\section{Methodology}

The sample of the study was carried out randomly, among the $1^{\text {st }}$ to $8^{\text {th }}$ Academicians of the Dental Course (UNIFEB). This study evaluated 106 students of both genders, aged between 18 and 33 years old, independent of race and dentition with at least 20 functional teeth, that is, they act effectively in the masticatory process.

The students were clarified regarding the research and only those who so decided participated, by signing the Term of Free and Informed Consent - TCLE, responding to a questionnaire 22.

There are innumerable methods to evaluate the presence of these habits in the patients' daily life, being the selfadministered questionnaire, that is, without the interference of the researcher/ examiner, is the most practical and consecrated in the national and international literature as valid 22 , and most widely performed [12,37].

This questionnaire contained items related to demographic information, age group, gender, medical history related to the use of medications, such as tranquilizers, parafunctional habits (tooth clenching, bruxism, nail biting, chewing lip, cheeks or objects).

Completion of the questionnaire was carried out by the academic [37]. To minimize any doubts of the interviewee, the questions belonging to the questionnaire were re-read, as well as the exchange of terms not understood by synonyms, in order to avoid interferences in the research result.

After completing the questionnaire, the students underwent a clinical examination to identify the presence of parafunctional habits, which consisted in identifying the presence or absence of: facets of dental wear, scalloped tongue and linea alba in the oral mucosa, which characterize the habit parafunctional Bruxism in both forms; centric bruxism (linea alba of occlusion and scalloped tongue) and eccentric bruxism (facets of tooth wear) according to the work of Seraidarian et al. [25]. The degree of dental wear, nor the extent and densities of the line of occlusion and scalloped tongue were not measured.

The data collected were recorded in the clinical file. The examination was performed by the same examiner. The intraexaminer reliability was evaluated by randomly selecting more than $10 \%$ of the sample for examination at different times, with an interval of one hour between the exams. The presence/ absence of scalloped tongue, linea alba and wear facets were considered, and in all three cases, $100 \%$ of the results of the first exam were coincident with the second. Due to the absence of non-coincident data, it was not possible to perform the Kappa 39 test.

\section{Results and Discussion}

The 106 undergraduate students of the UNIFEB Dentistry course from $1^{\text {st }}$ to $8^{\text {th }}$ terms who were examined comprised 70 women and 36 men aged 18 to 33 years. Age group confirmed as having a higher incidence of parafunctional habits and TMD [36].

The identification of parafunctional habits is proving to be important for the prevention and/or early treatment of TMD $[3,6,8,15,28-30]$.

The prevalence of parafunctional habits was assessed through $[12,22,37]$ and clinical examination. Some data, obtained in the questionnaire, were not used in the present study, such as the following questions: 1-Has any health problem; 2-makes use of medication; 8- did orthodontic treatment; 9-has dentin sensitivity.

The answers to the questions considered for the present study are presented in Table 1.

The questions on the questionnaire were based on a study of $[12,22,37,38]$. It can be observed in the questionnaire responses that the most prevalent habit was to place the hand on the chin (64.15\%), followed by the habit of grinding teeth (52.86\%); toenail $33.96 \%$; grinding teeth and biting tongue and cheek $29.25 \%$; bite the lip $26.42 \%$ and bite some object $12.26 \%$.

The habit of putting his hand on chin had the frequency of occurrence of $64.15 \%$, approaching the result obtained by Lavigne et al. [39] found that $73.5 \%$. However, this percentage was reduced to less than half, that is, $33.3 \%$ in the work of Miyake et al. [40].

The act of nail-biting performed in $33.96 \%$ of the students interviewed, according to [41-43] the most aggravating the act of nail biting would stress, leading the individual to self- mutilation 9.

According to Wells 28, nail-biting can be considered serious due to high frequency and intensity, causing physical damage and adverse social consequences. The dental surgeon plays a key role in identifying dental complications and the potential risk of this habit. For, in a study conducted by Feteih [44] and Ballinger, [45] a group of 0 to 70 years was found to have a nail-biting habit after a 40-year decline.

The sample was standardized for the psycho-emotional characteristics of the teaching institution, since they are all students of Dentistry, occupied the same facilities, received the same practical and theoretical content, by the same faculty, in each year of the Dentistry course. The hormonal, gender-related, and psychosocial variations of each individual are considered to be factors of great influence in the development of parafunctional activities, since each individual has his private life which is a factor that denotes a great difference between the results found.

The clinical examination carried out in all the participating students of the sample allowed us to observe that $97.17 \%$ of the

Table 1 Frequency and percentage of positive responses to the questionnaire.

\begin{tabular}{|c|c|c|}
\hline Questions & $\mathbf{N}^{\circ}$ & $\%$ \\
\hline Tighten your teeth? & 56 & $52,86 \%$ \\
\hline Range the teeth? & 31 & $29,25 \%$ \\
\hline Bite the lip & 28 & $26,42 \%$ \\
\hline Bites cheek or tongue & 31 & $29,25 \%$ \\
\hline Bite some object & 13 & $12,26 \%$ \\
\hline Put your hand on your chin & 68 & $64,15 \%$ \\
\hline Roe nail & 36 & $33,96 \%$ \\
\hline
\end{tabular}


sample has facets of tooth wear; $87.74 \%$ alba occlusion line and 83.01\% scalloped tongue, as shown in Figure 1.

Dental wear represents the main sign associated with bruxism [46-51] providing percentages varying from $6 \%$ to $20 \%$ of adults who, at some point, experience episodes of bruxism.

According to several studies [21,47,51-53], it has been demonstrated that bruxism is one of the parafunctional habits of higher prevalence and complexity. However, there is a marked difficulty in determining the prevalence of bruxism due to variation in the frequency and intensity of the episodes [54-56].

Centric bruxism is related to maxillo-mandibular clenching, which usually occurs during the day (on watch), in an isometric movement, in relation to centric occlusion or maximal intercuspation, without slipping. Eccentric bruxism characterizes the grinding of the teeth, where there is tightening and sliding mandibular in the protrusive and lateral- protrusive positions. There is an isotonic pattern of muscle contraction, presenting, as a function of slippage, wear in both anterior and posterior teeth [57].

According to studies carried out by 25 bruxism in its initial phase, its diagnosis would be difficult because it had to be reported by observation of the relatives, who could report on audible noise and discomfort produced by the patient during sleep, but at a later stage facets of wear [58]. Classify wear on incisal edges, especially on anterior teeth, such as eccentric bruxism.

The line of occlusion, tongue edges (scalloped) and presence of facets of wear on the incisal edges and occlusal surfaces of the teeth are clinical signs of parafunctional habits, signs observed in the present study $[59,60]$

Centric bruxism would be diagnosed by means of clinical examination for the presence of an albumin line in the jugal mucosa and scalloped tongue $[60,61]$. This was confirmed in the clinical examination of this study in $87.74 \%$ and $83.02 \%$ respectively, which contradict with $[44,62]$ that obtained a percentage of $8.3 \%$.

The data of the present study corroborate with 6 that affirms that the parafunctional activities happens unconsciously, being bruxism one of them.

The results found in this study indicate a higher occurrence of wear facets, observed in $97.17 \%$ for both genders. Individuals who have the habit of bruxism present rhythmic dental wear and period of tightening of the teeth [21]. As reported by $[6,63]$ the present work confirms the unconscious way in which parafunctional habits occur, especially bruxism. When comparing the answers obtained by the questionnaire and the results obtained by the clinical examination, different results can be observed, as shown in Table 2 .

The discrepancies between the data obtained by the questionnaire and the data of the clinical examination show the need for the professional to inform the patient about the problem, that their awareness is necessary to avoid harmful consequences to the stomatognathic system, since the parafunctional habits is still

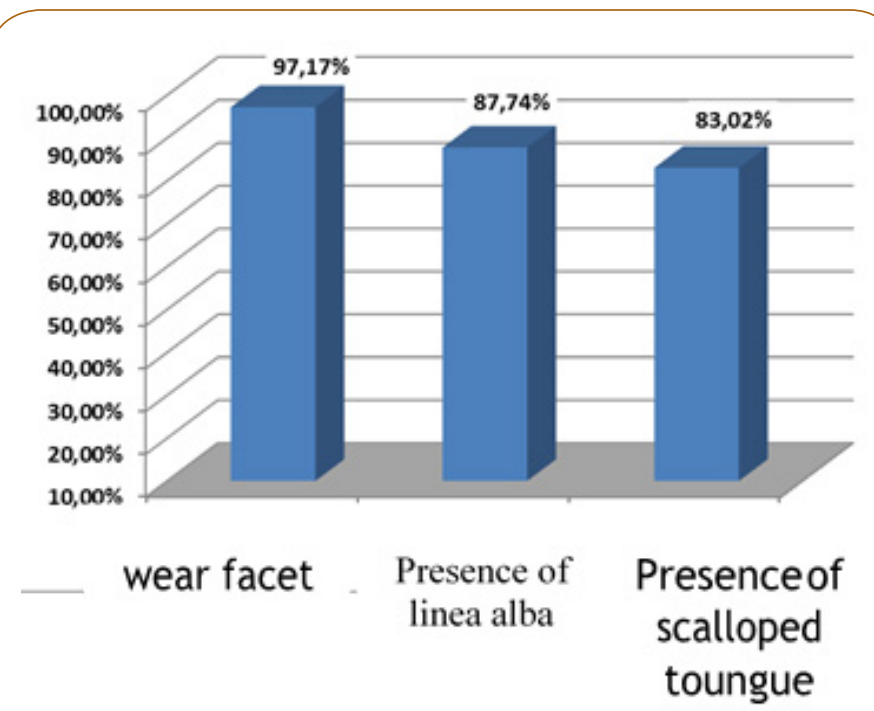

Figure 1

Percentage resulting from clinical examination.

Table 2 Discrepancy between signs found in the clinical examination (Line alba and scalloped tongue) and reported by the academicians in the questionnaire applied (habit of squeezing the teeth).

\begin{tabular}{|c|c|}
\hline Questionnaire & Clinical Examination \\
\hline $\begin{array}{c}\text { Range the teeth (Eccentric Bruxism) } \\
29,25 \%\end{array}$ & Facets of wear $97,17 \%$ \\
\hline $\begin{array}{c}\text { Clench the teeth (Central Bruxism) } \\
52,86 \%\end{array}$ & $\begin{array}{c}\text { Alaba Occlusion Line- } 87,74 \% \\
\text { Scalloped tongue }-83,01 \%\end{array}$ \\
\hline
\end{tabular}

a polemic subject in dentistry, both regarding etiology and the form of treatment $[14,25]$.

This can be read in research of Bianchini [33], where the author states that parafunctional oral habits may have a conscious form, although patients do not know their harms, thus demonstrating that the patient's awareness is also an important factor to avoid destabilization of the stomatognathic system.

Thus, the researched academics who answered the questionnaire about what habits they had, that is, were aware that they did, the data obtained were: teeth grinding - 52.83\%; $29.25 \%$ reported grinding teeth; $26,42 \%$ bite their lips; $29.25 \%$ reported biting cheek and tongue; $12.26 \%$ bite some object; $61.32 \%$ underwent orthodontic treatment; $30.19 \%$ reported tooth sensitivity; $64.15 \%$ have a habit of putting their hand on the chin and $33.96 \%$ reported gnawing nails.

The results found in this study; teeth were $48 \%$ and dental tightening was $56 \%$ that contradict studies published by Kampel 64 where $80 \%$ to $90 \%$ of the population developed bruxism, so it would be difficult to establish the prevalence of bruxism in the population due to the fact that some people creak and clench their teeth unconsciously.

Considering the high prevalence of bruxism and the irreversible consequences to the stomatognathic system, the dentist should seek the early diagnosis of parafunctional habits, since the complex and still obscure aetiology makes standard treatment impossible for all patients. to be concerned with the orientation 
of the patient with regard to the problem found, opting for a conservative control therapy and periodic reassessment to avoid greater damages [64].

What is confirmed in Dawson's [65] research, 2008, and still remains to the present day, that there is no specific treatment, the first function of the dentist in the choice of therapy is to treat the pain that is originated and irradiated from the masticatory structures identification of the prevailing etiological factors for the success of the treatment.

\section{Conclusion}

It is valid to conclude that:

\section{References}

1. Douglas CR (1998) Patofisiologia oral (Vol 1). São Paulo: Pancast, Pp: 381-382.

2. Lavigne GJ, Khoury S, Abe S, Yamaguchi T, Raphael K (2008) Bruxism physiology and pathology: an overview for clinicians. J Oral Rehabil 35: 476-494.

3. Paiva HJ, Vieira AMF, Cavalcante HCC, Medeiros ME, Gondim NFR, et al. (1997) Generalidades em oclusão: I hábitos parafuncionais - II gomas de mascar: prevenção e oclusão - III biomêcanica do estalido da ATM. In: Oclusão: noções e conceitos básicos (Paiva HJ Edn). São Paulo: Santos 14: 239-276.

4. de Leeuw R, Klasser GD (2013) Orofacial pain: guidelines for assessment, diagnosis and management ( $5^{\text {th }}$ Edn). Chicago: Quintessence Publishing Co, Inc, p: 312.

5. Kakudate N, Yokoyama Y, Sumida F, Matsumoto Y, Gordan VV, et al. (2017) Dentist practice patterns and therapeutic confidence in the treatment of pain related to temporomandibular disorders in a dental practice-based research network. J Oral Facial Pain Headache 31: 152-158.

6. Dawson PE (1993) Avaliação, diagnóstico e tratamento dos problemas oclusais (2 ${ }^{\text {nd }}$ Edn). São Paulo: Artes Médicas, pp: 492-499.

7. Rugh JD, Orbach R (1991) Parafunção oclusal. In: Fundamentos de oclusão (Mohl MD, Zarb GA, Carlsson GE Edn). São Paulo: Quintessence, Pp: 281-296.

8. Okeson JP (2000) Tratamento das desordens temporomandibulares e oclusão (4th Edn). São Paulo: Artes Médicas, Pp: 171-172.

9. Glaros AG, Williams K, Lausten L (2005) The role of parafunctions, emotions and stress in predicting facial pain. J Am Dent Assoc 136: 451-458.

10. Lobbezoo F, Ahlberg J, Glaros AG, Kato T, Koyano K, et al. (2013) Bruxism defined and graded: an international consensus. J Oral Rehabil 40: 2-4.

11. Pasinato F, Corrêa EC, Souza JA (2009) Avaliação do estado e traço de ansiedade em indivíduos com disfunção temporomandibular e assintomáticos. Saúde 35: 10-15.

12. Lavigne G, Kato $T$ (2005) Usual and unusual motor activities associated with tooth wear. Int J Prosthod 18: 291-292.

13. Raphael KG, Janal MN, Sirois DA, Svensson P (2013) Effect of contingent electrical stimulation on masticatory muscle activity and pain in patients with a myofascial temporomandibular disorder and sleep bruxism. J Orofac Pain 27: 21-31.
There was a high prevalence of parafunctional habits among the academics of the UNIFEB dentistry course.

The most observed parafunctional habit was bruxism, both in its centric and eccentric form.

The habit of supporting the hand in the chin had a high prevalence.

The habits of chewing nail, biting cheek or tongue presented similar and lower prevalence than those cited above.

There is a need for early diagnosis, guidance and awareness to reduce possible damage to the stomatognathic system, because people are not always aware of the presence of parafunctional habits, which are quite deleterious.

14. Barbosa JA, Swerts AA (2011) Prevalência da disfunção temporomandibular em graduandos do curso de Odontologia da Universidade José de Rosário Vellano - UNIFENAS, MG. Rev CROMG 12: $65-68$

15. http://www.bibliotecadigital.funvicpinda.org.br:8080/jspui/ bitstream/123456789/114/1/RodriguezFusco.pdf

16. Medeiros SP, Batista AU, Forte FD (2011) Prevalência de sintomas de disfunção temporomandibular e hábitos parafuncionais em estudantes universitários. Rev Gaúcha Odontol 59: 201-208.

17. Branco RS, Branco CS, de Souza Tesch R, Rapoport A (2008) Frequência de relatos de parafunções nos subgrupos diagnósticos de DTM de acordo com os critérios diagnósticos para pesquisa em disfunções temporo - mandibulares (RDC/TMD). Rev Dent Press Ortodon Ortop Facial 13: 61-69.

18. Siqueira JTT, Ching LH (1999) Dor orofacial/ATM bases para o diagnóstico clínico. MaioLtda 6: 209-233.

19. Okeson JP (2008) Etiology of functional disturbances in the masticatory system. In: Management of temporomandibular disorders and occlusion (6 ${ }^{\text {th }}$ Edn). St. Louis, MO: Mosby Pp: 105-131.

20. Alencar FGP (2005) Oclusão, dores orofaciais e cefaleia. Livraria Santos, Pp: 9-13.

21. Porter DR (1964) Implications and intercorrelations of oral habits. J Dent Clild 31: 164-170.

22. Okeson JP, Phillips BA, Berry DT, Baldwin RM (1994) Nocturnal bruxing events: a report of normative data and cardiovascular response. J Oral Rehabil 21: 623-630.

23. Manfredi APS, Silva AA, Vendite L (2001) Avaliação do questionário de disfunção temporomandibular recomendado pela Academia Americana de Dor orofacial. Rev Bras Otorrinolarig 67: 763-768.

24. Hanson ML, Barrett RH (1995) Fundamentos da Miologia Orofacial. Rio de Janeiro: Enelivros, p: 1192.

25. Vanderas AP (1995) Relationship between craniomandibular dysfunction and oral parafunctions in Caucasian children with and without unpleasant life events. J Oral Rehabil 22: 289-294.

26. Seraidarian PI, Assunção ZLV, Jacob MF (2001) Bruxismo: uma atualização dos conceitos, etiologia, prevalência e gerenciamento. JBA 1: 290-295.

27. Tomé MC, Farret MMB, Jurach EM (1996) Hábitos orais e maloclusão. In: Tópicos em fonoaudiologia (Marchesan I Edn). São Paulo: Lovise, Pp: 97-109. 
28. de Miranda Costa LF, Guimarães JP, Chaobah A (2004) Prevalência de distúrbios da articulação temporo- mandibular em crianças e adolescentes brasileiros e sua relação com má-oclusão e hábitos parafuncionais: um estudo epidemiológico transversal-parte ii: distúrbios articulares e hábitos para funcionais. J Bras Ortodon Ortop Facial 9: 162-169.

29. Wells JH, Haines J, Williams CL (1998) Severe morbid onychophagia: the classification as self-mutilation and a proposed model of maintenance. Aust N Z J Psychiatry 32: 534-545.

30. Regis RR, Souza RF, Paranhos HFO (2007) Severe lesion caused by onychophagia. Rev odontol UNESP 36: 379-382.

31. Miltenberger RG, Fuaua RW, Woods DW (1998) Applying behavior analysis to clinical problems: review and analysis of habit reversal. $J$ Appl Behav Anal 31: 447-469.

32. Alves-Rezende MC, Silva JS, Soares BM, Bertoz FA, Oliveira DT, et al. (2009) Estudo da prevalência de sintomatologia temporomandibular em universitários brasileiros de odontologia. Rev Odon Araç 30: 9-14.

33. Bianchini EMG (1998) Mastigação e ATM. In: Fundamentos em fonoaudiologia: aspectos clínicos da motricidade oral (Marchesan IQ Edn). Rio de Janeiro: Guanabara Koogan, Pp: 39-49.

34. Serra-Negra JM, Lobbezoo F, Martins CC, Stellini E, Manfredini D (2017) Prevalence of sleep bruxism and awake bruxism in different chronotype profiles: hypothesis of an association. Med Hypotheses 101: 55-58.

35. Melchior MO, Mazzetto MO, Felício CM (2012) Temporomandibular disorders and parafunctional oral habits: an anamnestic study. Dental Press J Orthod 17: 83-89.

36. Minghelli B, Morgado M, Caro T (2014) Association of temporomandibular disorder symptoms with anxiety and depression in Portuguese college students. J Oral Sci 56: 127-133.

37. Moraes JV, Bottino MA (1972) Papel da oclusão nos distúrbios da articulação temporomandibular. Revista da Faculdade de Odontologia de São José dos Campos 1: 27-31.

38. Gonçalves DA, Dal Fabbro AL, Campos JA, Bigail ME, Speciali JG (2010) Symptoms of temporomandibular disorders in the population: an epidemiological study. J Orofac Pain 24: 270-278.

39. Lavigne GJ, Goulet JP, Morisson F, Montplaisir JY (1994) Le bruxisme, un vieux problem vu sous une perspective nouvelle. Réalités Cliniques 5: 199-207.

40. Miyake R, Ohkubo R, Takehara J, Morita M (2004) Oral parafunctions and association with symptoms of temporomandibular disorders in Japanese university students. J Oral Rehabil 1: 518-523.

41. Leão E Silva FM (2006) Lesões cervicais não cariosas: Presença, severidade e correlação com fatores etiológicos (tese). Uberlândia: Faculdade de Odontologia da Universidade Federal de Uberlândia.

42. Silva JAMG, Filho AVD, Machado AA, Oliveira LEM, Navega MT (2012) Correlation between self-esteem and degree of severity of temporomandibular dysfunction in control and affected subjects. Rev Odontol 41: 377-383.

43. Deardoff PA, Finch AJ Jr, Royall LR(1974) Manifest anxiety and nailbiting. J Clin Psychol 30: 378.

44. Feteih RM (2006) Signs and symptoms of temporomandibular disorders and oral parafunctions in urban Saudi Arabian adolescents: a research report. Head Face Med 25: 1-7.

45. Ballinger BR (1970) The prevalence of nail biting in normal and abnormal populations. Br J Psychiatry117: 445-446.

46. Leung AK, Robson WL (1990) Nailbiting. Clin Pediatr 29: 690-692.

47. Leonard HL, Lenane MC, Swedo SE, Rettew DC, Rapopartt JL (1991) A double-blind comparison of clomipramine and desipramine treatment of severe onychophagia (nail biting). Arch Gen Psychiatry 48: 821-827.

48. Brocard D, Laluque JF, Knellesen C (2010) Bruxismo Diagnóstico e Tratamento. Quintenssense Publishers 1: 11-12.

49. Glaros AG (1981) Incidence of diurnal and nocturnal bruxism. J Prosthet Dent 45: 545-549.

50. Goulet JP, Lund JP, Montplaisir JY, Lavigne GJ (1993) Daily clenching, nocturnal bruxism, and stress and their association with TMD symptoms. J Orofac Pain 7: 120.

51. Lavigne GL, Lobbezzo F, Rompté PH, Nielsen TA, Mont Plaisir JY (1997) Cigarette smoking as a risk factor or a exacerbating factor for restless legs syndrome an sleep bruxism. Sleep 20: 290-293.

52. Nadler SC (1957) Bruxism, a classification: critical review. J Am Dent Assoc 54: 615-622.

53. Pavone BW (1985) Bruxism and its effect on the natural teeth. J Prosthet Dent 53: 692-696.

54. Guedes F, Bonfante G (2001) Desordens temporomandibulares em crianças. JBA 1: 39-43.

55. Attanasio R (1991) Nocturnal Bruxism and its clinical management. Dent Clin North Am 35: 245-252.

56. Abraham J, Pierce C, Rinchuse D, Zullo T(1992) Assessment of buccal separators in the relief of bruxist activity associated with myofacial pain-dysfunction. Angle Orthod 62: 177-184.

57. Pertes RA, Gross SG Edn (1995) Clinical management of temporomandibular disorders and orofacial pain. Quintessence Publishing p: 368.

58. Sapiro SM (1992) Tongue indentations as an indicator of clenching. Clin Prev Dent 14: 21-24.

59. Ortega AC (1988) Tratamiento del bruxismo. Rev Actul Estomatol Esp 48: 33-87.

60. Mendes WB, Miyashita E, Oliveira GG (2011) Reabilitação oral: previsibilidade e longevidade. Napoleão Publishers 8: 228-247.

61. Neville BW, Dam DD (1998) Patologia oral e maxilofacial. Rio de Janeiro: Guanabara Koogan, p: 205.

62. Leung AKC, Robson WM (1991) Bruxism. How to stop tooth to grinding and clenching. Posgrad Med 89: 167-171.

63. Winocur E, Gavish A, Finkelshtein T, Halachmi M, Gazit E (2001) Oral habits among adolescent girls and their association with symptoms of temporomandibular disorders. J Oral Rehabi 28: 624-629.

64. Kampel T, Tagdae T, Bader G, Edman G, Karlsson S (1997) Reported symptoms and clinical findings in a group of subjects with longstanding bruxing behavior. J Oral Rehabil 24: 581-587.

65. Dawson PE (2008) Oclusão functional: da ATM ao desenho do sorriso. In: Oclusão (Dawson PE Edn). São Paulo: Santos, 28: 33. 